\title{
Application of GSMaP Product and Rain Gauge Data for Monitoring Rainfall Condition of Flood Events in Indonesia
}

\author{
Nyoman Sugiartha a,b*, Kakuji Ogawara a, Tasuku Tanaka c, \\ Made Sudiana Mahendra d \\ a Department of Mechanical Engineering, Graduate School of Sciences and Technology for Innovation, Yamaguchi \\ University, 2-16-1 Tokiwadai, Ube, Yamaguchi 755-8611, Japan \\ ${ }^{b}$ Department of Mechanical Engineering, Bali State Polytechnic, Bukit Jimbaran, Kuta Selatan, Bali 80361, \\ Indonesia \\ c Center for Remote Sensing and Ocean Science (CReSOS), Udayana University, PB Sudirman Street, Post Graduate \\ Building, Denpasar, Bali 80232, Indonesia \\ d Graduate School of Environmental Sciences, Udayana University, PB Sudirman Street, Post Graduate Building, \\ Denpasar, Bali 80232, Indonesia \\ *Correspondence: nyoman.sugiartha@yahoo.co.uk
}

Received: 19 July 2016; Accepted: 28 February 2017; Available online: 14 March 2017

\begin{abstract}
Rainfall is one of main causes of floods. Monitoring of the rainfall is essential for understanding flood mechanism and early warning. Ground-based rain gauge is a conventional device to measure rainfall amount and considered as a point measurement. Satellite-based rainfall estimates provides complement measurement over wide area having few or even no in situ data. This study evaluates rainfall intensity variation and patterns preceding flood events in Indonesia for the period of 20032010 using the GSMaP_MVK satellite-based rainfall product with one hour and $0.1^{\circ} \mathrm{x} 0.1^{\circ}$ resolutions and rain gauge station data as a benchmark. The analysed data are 3-hourly average and daily accumulation time steps. The chosen research locations were Medan City, Pekanbaru City, Indragiri Hulu Regency, Samarinda City and Manado City. Graphical comparisons of the GSMaP_MVK with the rain gauge data show discrepancies in capturing rainfall events and intensity. The GSMaP_MVK performs underestimation for the most areas, except Samarinda City, which is overestimated. Short-term period rainfall pattern is the most frequent occurred preceding flood events for the entire study areas which indicate that the areas are more susceptible to flash floods and river overflows. Overall, the GSMaP_MVK product provides promising potentiality for the application of monitoring rainfall conditions preceding flood events over the research locations. Statistical verifications reveal that on average, correlation coefficients are $(0.22-0.54)$ and $(0.65-$ 0.83 ) for 3-hourly and daily scale, respectively. While, probability of rain detections (PODs) are (0.57-0.75) and (0.93-0.99), accordingly.
\end{abstract}

Keywords: rainfall; monitoring; accuracy; GSMaP MVK; rain gauge; flood events

\section{Introduction}

Flood is a prevalent threatening natural disaster in Indonesia and spreading in many places throughout the country. Within the period of 2003-2010, there were about 5,186 flood disaster incidences, which accounted for $45.5 \%$ of the total natural disasters (BNPB, 2013). Rainfall is commonly known as one of major factors triggering the flood. Amount of rain falls during certain period of time over the area could determine how fast the flood starts to occur. The study of rainfall is thus of fundamental importance for understanding flood mechanism and early warning.

According to Kidd and Huffman (2011) monitoring and measurement of the rainfall is crucial to our well-being and critical to the application in hydrological and water 
resources management. The information on rainfall variations preceding flood events in conjunction with the application of hydrological model is essential for establishing a reliable flood early warning system. Subsequently, providing real time or very near real time rainfall data are mandatory to support such a system. In general, there are two sources to collect rainfall data, i.e. conventional rain gauge networks and remote sensing systems, such as ground-based weather radar and satellites.

The rain gauge is a relatively simple instrument which directly samples the rain by accumulating rain drops continuously over a fixed time interval at individual locations. With a good rain gauges network, it is possible to map rainfall over small areas but this approach is not practical for large areas, remote land areas of the globe or for oceans (Strangeways, 2007; Mustafa, 2007). The rain gauge observations are usually considered as a reference or ground truth due to a fairly accurate and reliable measurement with a very low error but its spatial coverage is limited (Sinclair and Pegram, 2005; Ciach and Krajewski 1999).

Satellite-based rainfall data add valuable information to climate databases due to their wide geographical coverage, especially over areas with few or completely missing in situ data (WMO, 2011). The satellite-based rainfall data has the potential to become a cost effective source of input for flood predictions under a variety of circumstances in comparison with the in situ network measurements. This is due to their increasingly available on a global basis from the internet and uninterrupted during catastrophic situations (Harris et al., 2007).

Global Satellite Mapping of Precipitation (GSMaP) is one of the global high-resolution satellite-based precipitation products (HRPP) that is freely accessible via internet. The GSMaP provides rainfall product with one hour temporal resolution and 0.1 degree of latitude by 0.1 degree of longitude spatial resolutions based on the deterministic rainretrieval algorithm of Aonashi and Liu (2000) with comprehensively analysing satellite microwave radiometer data including infrared (IR) data (Okamoto et al., 2007; Kubota et al., 2007; Seto et al., 2012). The GSMaP and its global precipitation maps are therefore appealing for a wide range of hydrological applications, such as flood monitoring and forecasting (Tian et al., 2010).

The main objective of the study is to evaluate potentiality of the GSMaP_MVK product in comparison with the rain gauge data for monitoring rainfall condition of the flood events in Indonesia, especially in Medan City, Indragiri Hulu Regency, Pekanbaru City, Samarinda City and Manado City. The specific objectives include: (1) to compare variations of rainfall intensity of the flood events as observed by the GSMaP_MVK product with that measured by rain gauge station; (2) to identify pattern of rainfall preceding flood events based on the GSMaP_MVK product estimates and the rain gauge measurements; and (3) to verify accuracy of the GSMaP_MVK product estimates versus the rain gauge measurements using continuous and categorical verification statistic scores (i.e. ME, MAE, RMSE, correlation coefficient, POD, FAR and TS).

\section{Materials and Methods}

\subsection{Framework of Research}

The framework of research was designed based on the objectives of the study. The research was generally outlined into three main stages in terms of data treatment, i.e. collecting, processing, analysing and presenting data. Schematic diagram of the research framework is shown in Figure 1.

The first stage was to collect relevant data. The data include flood events (i.e. the day of the flood starts to occur) and rainfall intensity from one hourly GSMaP_MVK product and 3 -hourly and daily rain gauge data. The rainfall intensity was for 10 days preceding and 2 days following the flood events. Number of the flood events analysed during 2003-2010 was 11, 10, 9 and 6 for Medan City, Indragiri Hulu Regency and Pekanbaru City, Samarinda City and Manado City, respectively.

The second stage was to process the data. The rainfall intensity of the GSMaP_MVK on hourly basis were calculated using OpenGrADS software by area averaging of the satellite pixel $\left(0.1^{0} \times 0.1^{\circ}\right)$ in which the rain gauge station is located (Figure 2). The rainfall intensity value on a pixel is a single value of the satellite rainfall estimates. The 
GSMaP_MVK rainfall intensity was then converted from hourly to 3-hourly and daily time steps. The most popular way to make 3-hourly average from hourly data is by averaging hourly files of $02 Z, 03 Z$, and $04 Z$ to produce 3 -hourly data of $03 Z$. That means $03 Z$ is centre of 3 hour time period. The daily data are derived by summing hourly data from $00 Z$ to $23 Z$ on the day. Table 1 shows available rain gauge stations, for which data were analysed and the corresponding GSMaP_MVK pixel that were chosen for comparison.

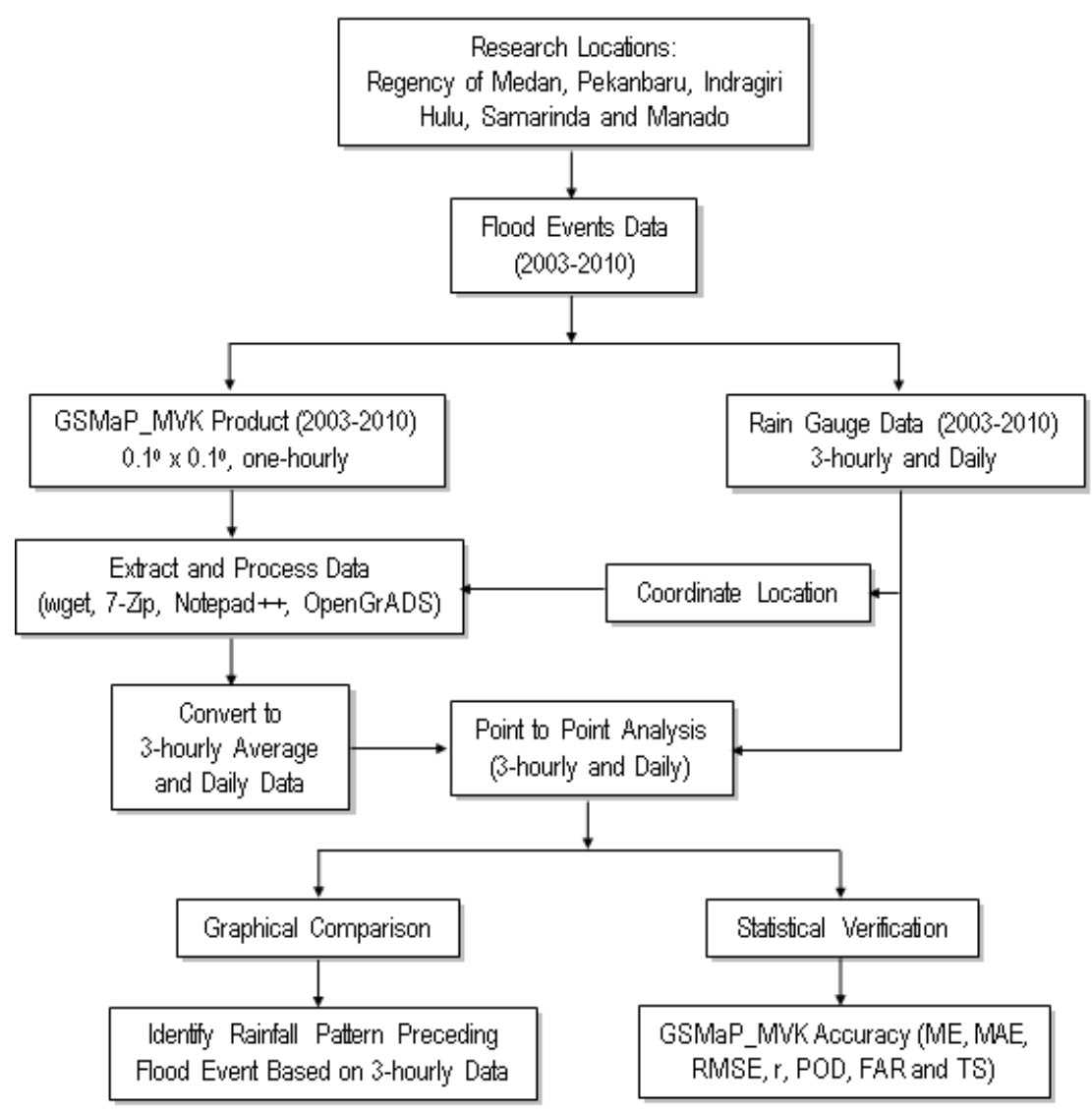

Figure 1. Schematic diagram of the research framework

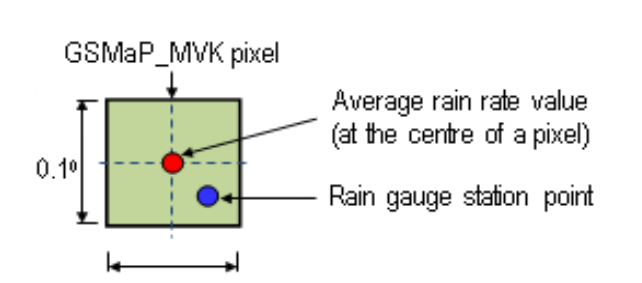

Figure 2. Example of the GSMaP_MVK single pixel and the rain gauge station location

The third stage was to compare rainfall data of the GSMaP_MVK with the rain gauge station by firstly arranging a spreadsheet table. Point to point analysis method was applied in this study. Comparison of the GSMaP_MVK, which is represented by the single value of a pixel were performed head to head with the rain gauge point value within the satellite pixel. This is due to the very limited rain gauge station available in the study area (i.e. only one station for each study area).

Time series of the rainfall intensity from the GSMaP_MVK and the rain gauge data were presented for 3-hourly average and daily accumulation time steps. This was made in an attempt to understand the difference of the two measurements in capturing rainfall event fluctuations before and after the floods occur. Aryastana et al. (2012) developed classification of rainfall patterns before floods occur in Indonesia based on hourly data of the GSMaP_MVK product. In this study, however, both the GSMaP_MVK and the rain gauge data were used for determining the rainfall patterns on the basis of the 3-hourly 
average time steps. Subsequently, accuracy verification was conducted to evaluate the GSMaP_MVK applicability over the study areas with respect to the rain gauge data using statistical verification approach.

Table 1. Available rain gauge stations and the corresponding GSMaP_MVK pixel

\begin{tabular}{|c|c|c|c|c|c|}
\hline Province & Regency & $\begin{array}{l}\text { Rain Gauge } \\
\text { Station }\end{array}$ & Coordinate Position & $\begin{array}{l}\text { Elevation } \\
\quad(\mathrm{m})\end{array}$ & $\begin{array}{c}\text { Center of GSMaP_MVK } \\
\text { Pixel }\end{array}$ \\
\hline $\begin{array}{l}\text { North } \\
\text { Sumatera }\end{array}$ & Medan City & Polonia & $3.56^{\circ} \mathrm{N}, 98.67^{\circ} \mathrm{E}$ & 25 & $\begin{array}{c}3.50^{\circ} \mathrm{N}-3.50^{\circ} \mathrm{N} \\
98.60^{\circ} \mathrm{E}-98.70^{\circ} \mathrm{E}\end{array}$ \\
\hline Riau & $\begin{array}{l}\text { Pekanbaru } \\
\text { City }\end{array}$ & $\begin{array}{l}\text { Sutan Syarif } \\
\text { Kasim II }\end{array}$ & $0.46^{\circ} \mathrm{N}, 101.44^{\circ} \mathrm{E}$ & 31 & $\begin{array}{c}0.40^{\circ} \mathrm{N}-0.50^{\circ} \mathrm{N} \\
101.40^{\circ} \mathrm{E}-101.50^{\circ} \mathrm{E}\end{array}$ \\
\hline Riau & $\begin{array}{l}\text { Indragiri } \\
\text { Hulu }\end{array}$ & $\begin{array}{l}\text { Sutan Syarif } \\
\text { Kasim II }\end{array}$ & $0.46^{\circ} \mathrm{N}, 101.44^{\circ} \mathrm{E}$ & 31 & $\begin{array}{c}0.40^{\circ} \mathrm{N}-0.50^{\circ} \mathrm{N} \\
101.40^{\circ} \mathrm{E}-101.50^{\circ} \mathrm{E}\end{array}$ \\
\hline $\begin{array}{c}\text { East } \\
\text { Kalimantan }\end{array}$ & $\begin{array}{l}\text { Samarinda } \\
\text { City }\end{array}$ & Temindung & $0.48^{\circ} \mathrm{S}, 117.16^{\circ} \mathrm{E}$ & 3 & $\begin{array}{c}0.40^{\circ} \mathrm{S}-0.50^{\circ} \mathrm{S} \\
117.10^{\circ} \mathrm{E}-117.20^{\circ} \mathrm{E}\end{array}$ \\
\hline $\begin{array}{l}\text { North } \\
\text { Sulawesi }\end{array}$ & $\begin{array}{l}\text { Manado } \\
\text { City }\end{array}$ & $\begin{array}{l}\text { Sam } \\
\text { Ratulangi }\end{array}$ & $1.55^{\circ} \mathrm{N}, 124.93^{\circ} \mathrm{E}$ & 80 & $\begin{array}{c}1.50^{\circ} \mathrm{N}-1.60^{\circ} \mathrm{N} \\
124.90^{\circ} \mathrm{E}-125.00^{\circ} \mathrm{E}\end{array}$ \\
\hline
\end{tabular}

\subsection{Statistical Verification}

According to Ebert (2007), statistical method to verify accuracy of the satellite rainfall estimates compared with the observed rain gauge values include continuous verification statistics and categorical verification statistics.

The continuous verification statistics measure accuracy of a continuous variable such as rain amount or intensity. In this study, the statistics measures used include mean error (ME), mean absolute error (MAE), root mean square error (RMSE), and correlation coefficient $(r)$. In the equations to follow, $Y_{i}$ indicates the estimated value at point or grid box $i, \mathrm{O}_{i}$ indicates the observed value, and $\mathrm{N}$ is the number of samples (Ebert, 2007).

$$
\begin{aligned}
& M E=\frac{1}{N} \sum_{i=1}^{N}\left(Y_{i}-O_{i}\right) \\
& M A E=\frac{1}{N} \sum_{i=1}^{N}\left|\left(Y_{i}-O_{i}\right)\right| \\
& R M S E=\sqrt{\frac{1}{N} \sum_{i=1}^{N}\left(Y_{i}-O_{i}\right)^{2}} \\
& r=\frac{\sum_{i=1}^{N}\left(Y_{i}-\bar{Y}\right)\left(O_{i}-\bar{O}\right)}{\sqrt{\sum_{i=1}^{N}\left(Y_{i}-\bar{Y}\right)^{2} \sqrt{\sum_{i=1}^{N}\left(O_{i}-\bar{O}\right)^{2}}}} \\
& \bar{Y}=\frac{1}{N} \sum_{i=1}^{N} Y_{i} \\
& \bar{O}=\frac{1}{N} \sum_{i=1}^{N} O_{i}
\end{aligned}
$$

The categorical verification statistics measure correspondence between the estimated and observed occurrence of events, such as probability of rain detection (POD), false 
alarm ratio (FAR), and threat score (TS) (Ebert, 2007). Most are based on a $2 \times 2$ contingency table of yes/no events, such as rain/no rain as shown in Table 2.

$$
\begin{aligned}
& P O D=\frac{\text { Hits }}{\text { Hits }+ \text { Misses }} \\
& F A R=\frac{\text { False alarms }}{\text { Hits }+ \text { False alarms }} \\
& T S=\frac{\text { Hits }}{\text { Hits }+ \text { Misses }+ \text { False alarms }}
\end{aligned}
$$

Table 2. The off-diagonal elements characterise the errors $(2 \times 2$ contingency table $)$, reproduced from Ebert (2007)

\begin{tabular}{lcccc}
\hline \multirow{2}{*}{ Contingency table } & \multicolumn{3}{c}{$\begin{array}{c}\text { Observed } \\
\text { (Rain Gauge Data) }\end{array}$} \\
\cline { 2 - 5 } & & Yes & No & \\
\hline Estimated & Yes & Hits & False alarms & Estimated yes \\
(GSMaP_MVK) & No & Misses & Correct negatives & Estimated no \\
\hline & & Observed yes & Observed no & N=total \\
\hline
\end{tabular}

\section{Results}

\subsection{Rainfall Condition of Flood Event}

Figure 3 shows comparison of 3-hourly variations of rainfall intensity for the flood event in Medan City on 5 December 2003 obtained from the GSMaP_MVK and the rain gauge data. The dash-line circle indicates the day of the flood began. The total number of data points is 104 . The GSMaP_MVK indicated overestimation about $3 \mathrm{~mm} / \mathrm{h}$ of the rain gauge data for the two consecutive peaks starting 9 days preceding flood event. The GSMaP_MVK detected about 7 rainfall events up to $1.26 \mathrm{~mm} / \mathrm{h}$ intensity in which the rain gauge data did not observed them. Both the GSMaP_MVK and the rain gauge data show good agreement that no heavy rainfall observed 5 days before the day of flooding reported. Meanwhile, daily rainfall intensity variation is depicted in Figure 4. The highest rainfall peak 7 days preceding flood event was $43.90 \mathrm{~mm} /$ day and $57 \mathrm{~mm} /$ day as measured by the GSMaP_MVK and the rain gauge, respectively.

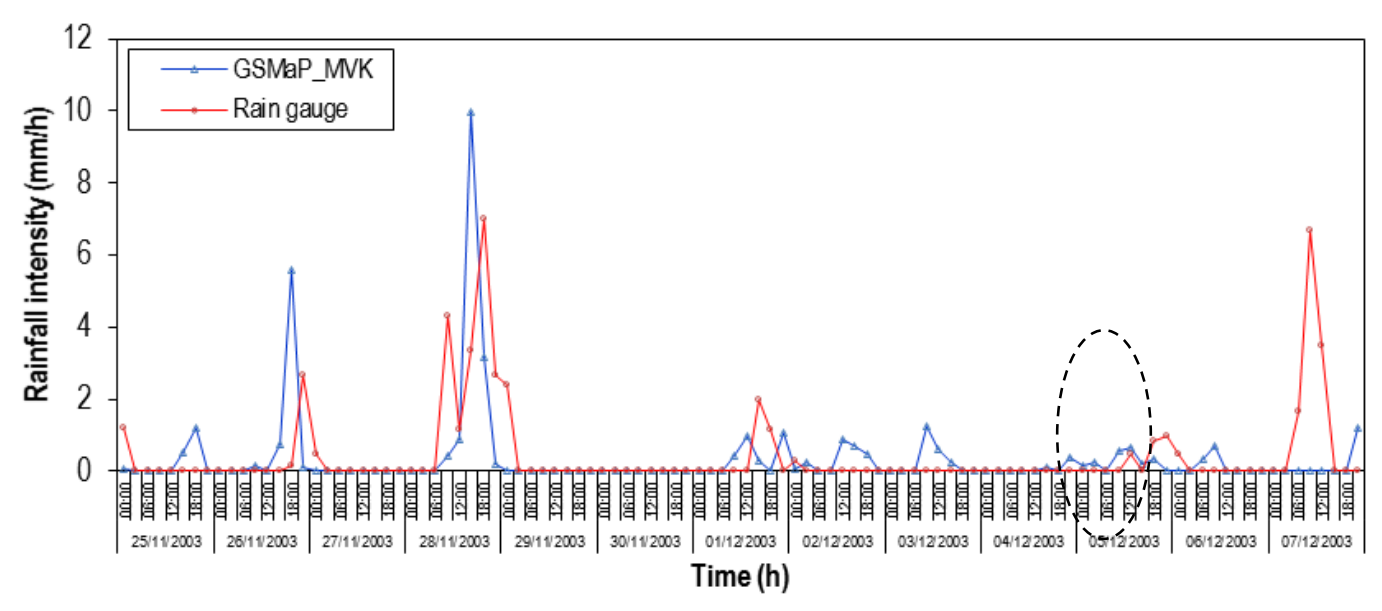

Figure 3. Time-series of 3-hourly average rainfall intensity for the flood event in Medan City on 5 December 2003. 


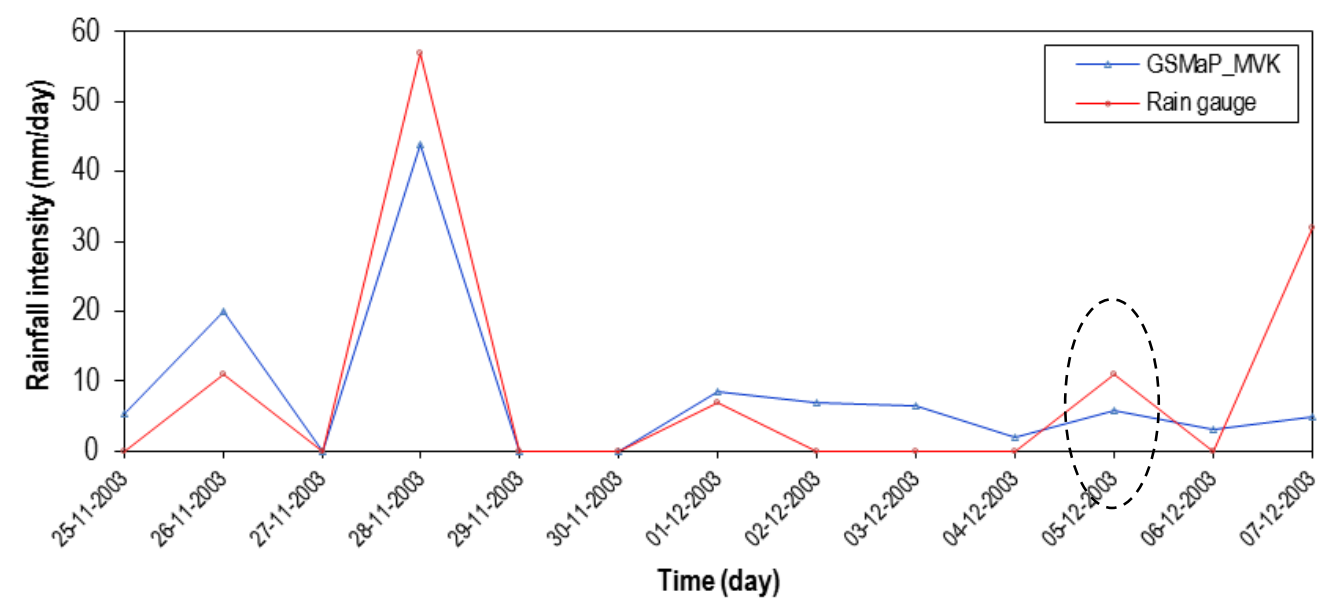

Figure 4. Same as Figure 3, but for daily data.

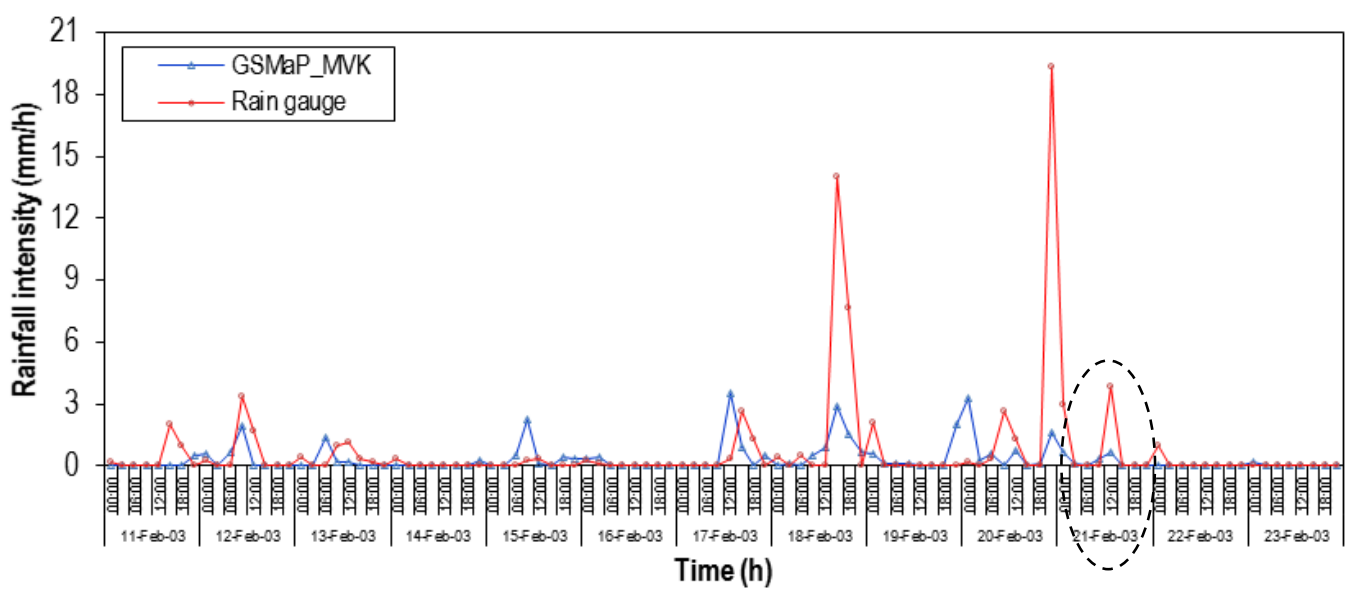

Figure 5. Time-series of 3-hourly average rainfall intensity for the flood event in Indragiri Hulu Regency and Pekanbaru City on 21 February 2003.

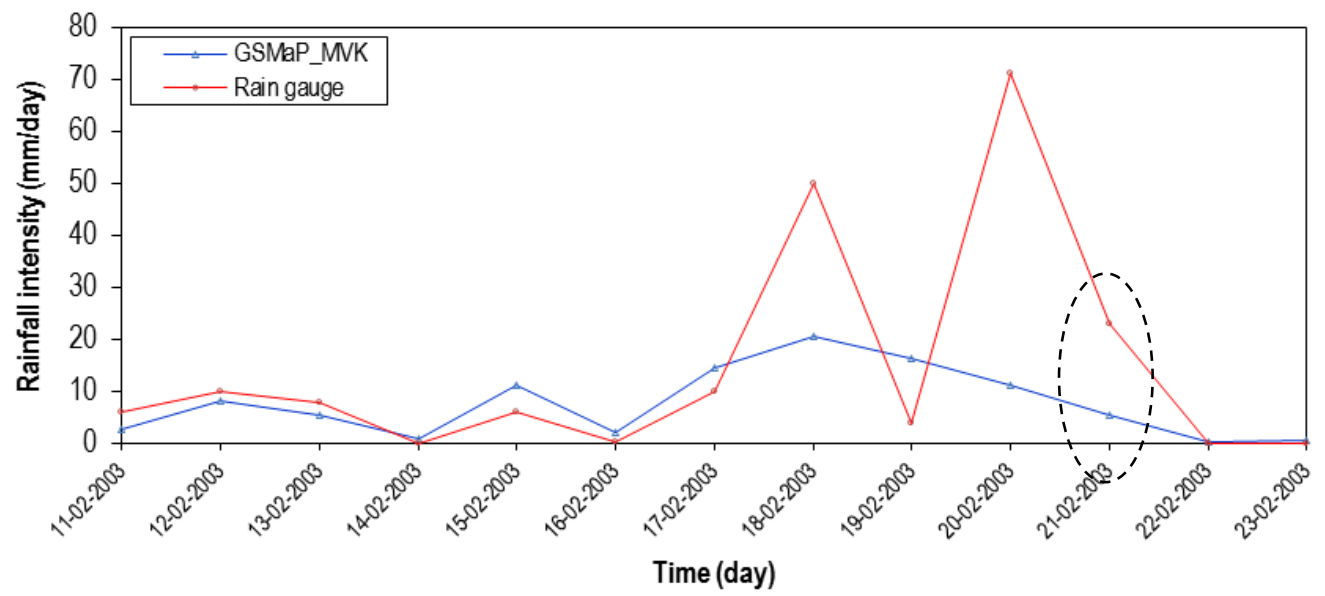

Figure 6. Same as Figure 5, but for daily data.

Figure 5 shows comparison of the 3-hourly variations of rainfall intensity between the GSMaP_MVK and the rain gauge data for the flood event in Indragiri Hulu Regency and Pekanbaru City on 21 February 2003. The GSMaP_MVK estimated rainfall intensity about $1.64 \mathrm{~mm} / \mathrm{h}$ compared with $19.33 \mathrm{~mm} / \mathrm{h}$ by the rain gauge measurement for 3 hours before the flood began. It represents approximately a $91.5 \%$ of underestimation. This is the highest rainfall intensity observed by the rain gauge data within less than 6 hours before the flood began that might be triggering the flood. The daily observations (Figure 6) 
show better matching of capturing peaks and rainfall intensity than the 3-hourly data. One day before the flood began the GSMaP_MVK estimated about $85 \%$ lower than that of the rain gauge data, which were $11 \mathrm{~mm} /$ day and $71 \mathrm{~mm} /$ day, respectively.

Figure 7 shows comparison of the 3-hourly variations of rainfall intensity between the GSMaP_MVK and rain gauge data for the flood event in Samarinda City on 7 May 2004. The GSMaP_MVK missed detection for rainfall event on 1 May 2004 from 09:00 (UTC) to 15:00 (UTC) while the rain gauge station observed it. On the contrary, the GSMaP_MVK estimated the rainfall occurred on the day of the flood began at 00:00 (UTC) but the rain gauge data did not observed it. The GSMaP_MVK estimated rainfall intensity of 106.4 $\mathrm{mm} /$ day on the day of the flood began compared with the rain gauge data of $64 \mathrm{~mm} /$ day (Figure 8). It shows approximately a $44.7 \%$ of overestimation.

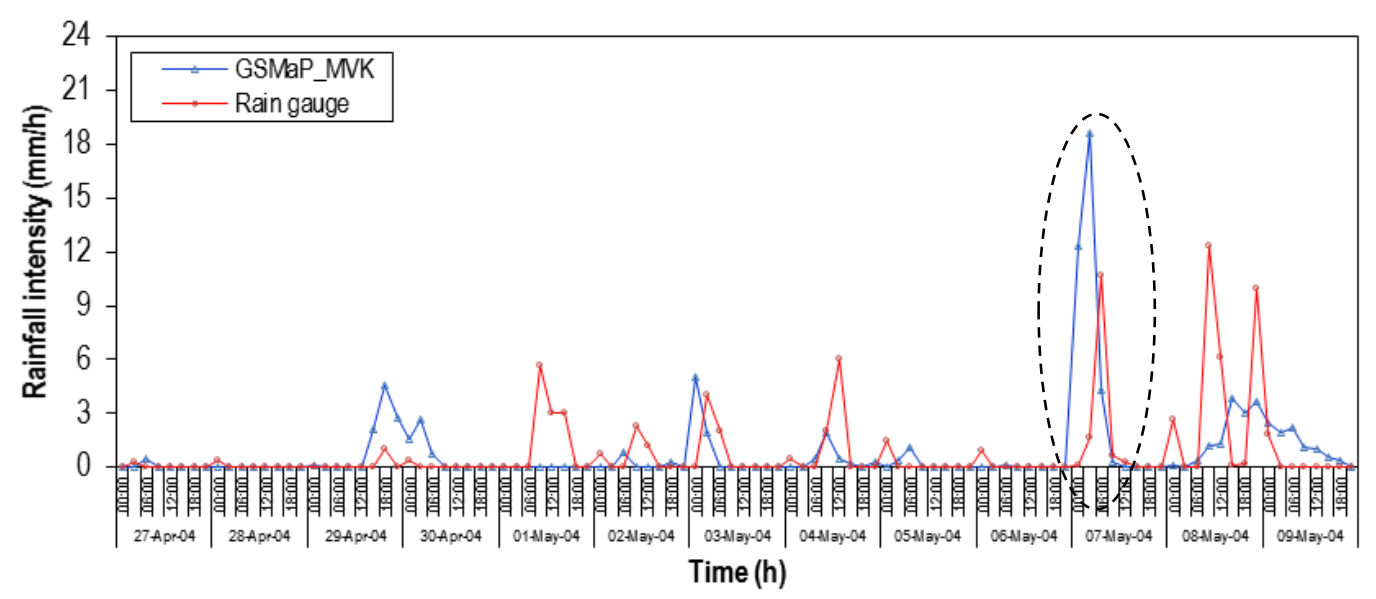

Figure 7. Time-series of 3-hourly average rainfall intensity for the flood event in Samarinda City on 7 May 2004.

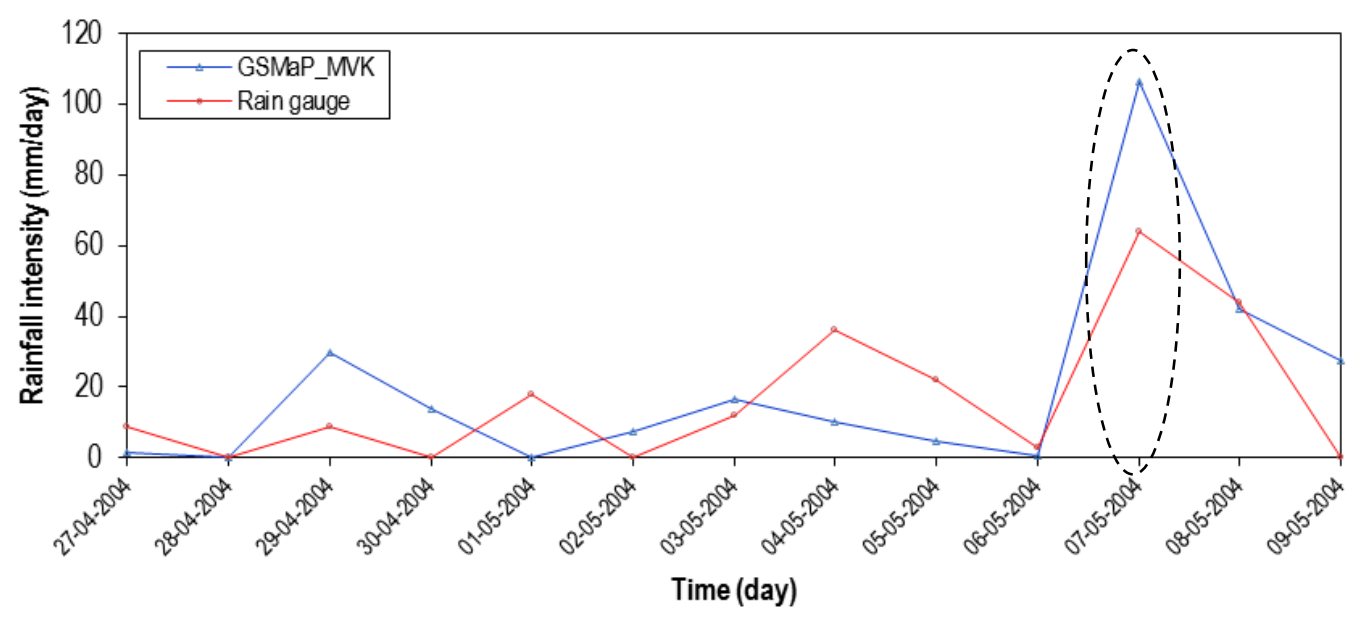

Figure 8. Same as Figure 7, but for daily data.

Figure 9 shows time series of the 3-hourly average rainfall intensity for the flood event in Manado City on 26 December 2003. The GSMaP_MVK underestimated rainfall intensity of about $72 \%$ during the highest peak observed by the rain gauge from 18 December 2003 to 19 December 2003. Accumulative rainfall mostly observed by the rain gauge 3 days before the flood began with the highest peak is $5.33 \mathrm{~mm} / \mathrm{h}$, while the GSMaP_MVK detected the highest peak of $3.5 \mathrm{~mm} / \mathrm{h}$ one day before flooding. The GSMaP_MVK estimated rainfall intensity of $16.5 \mathrm{~mm} /$ day one day before flood began compared with the rain gauge data of $32 \mathrm{~mm} /$ day (Figure 10). It represents approximately a $48 \%$ of underestimation.

In general, graphical comparisons between the GSMaP_MVK and rain gauge data show discrepancies in capturing rainfall events and intensity of preceding and following the 
flood events over Medan City, Pekanbaru City, Indragiri Hulu Regency, Samarinda City and Manado City for the 3-hourly average and daily time steps data. According to Sorooshian et al. (2011), it is well known that the discrepancy between satellite estimates and ground-rain gauge observations is not limited to the magnitude of rain rates but also includes rainfall patterns and geometrical features. This is also complicated by the nature of the rain gauge, which conventionally measures the rainfall as an integral of time at a point in space, whereas satellites measure an integral of space at a point in time (Kidd et al., 2003).

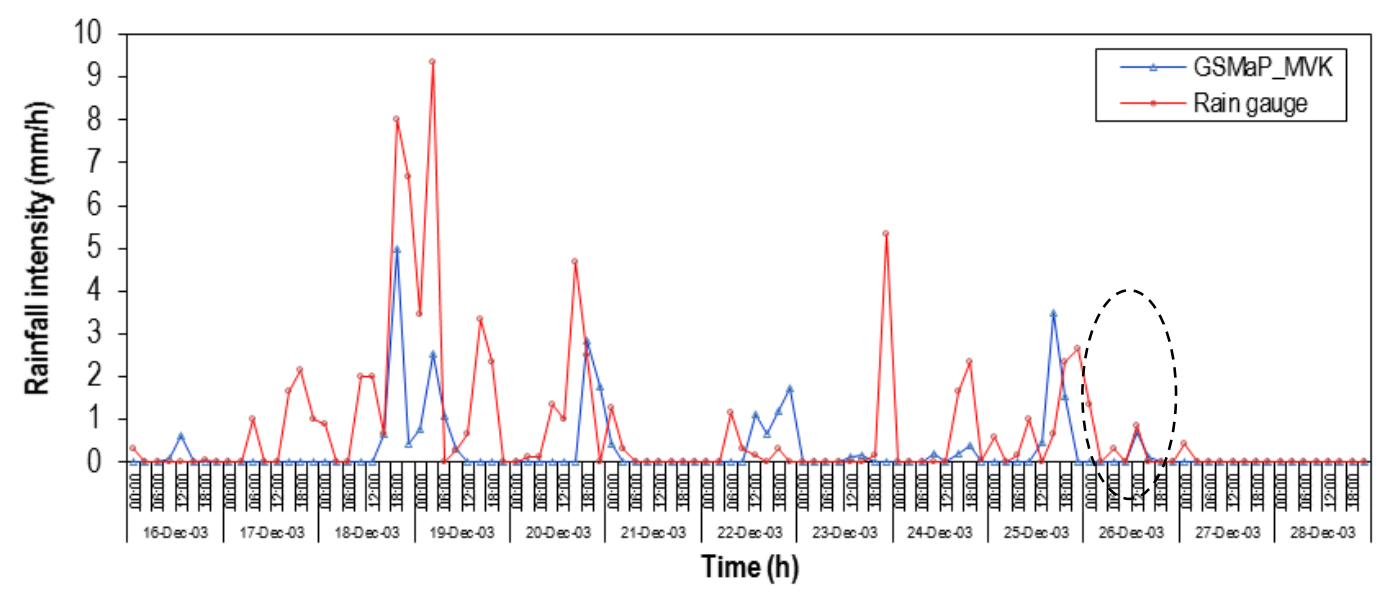

Figure 9. Time-series of 3-hourly average rainfall intensity for the flood event in Manado City on 26 December 2003.

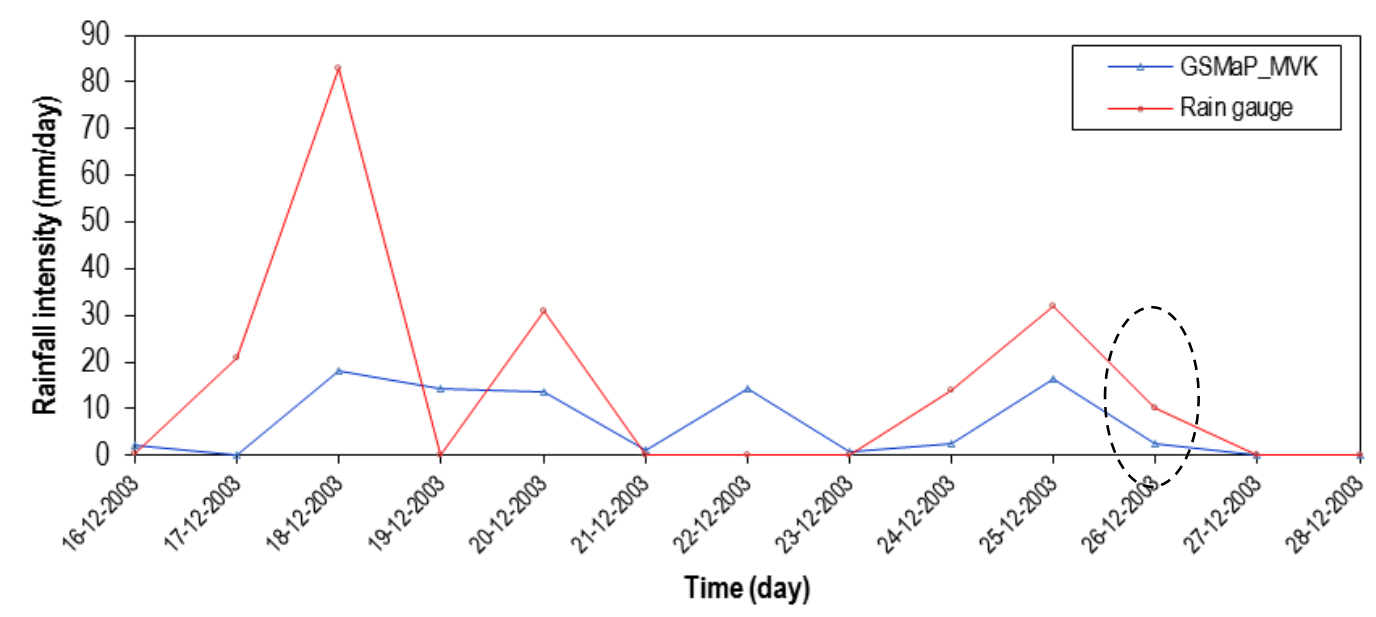

Figure 10. Same as Figure 9, but for daily data.

Comparing with the 3-hourly average scale, the daily observations show better matching of capturing the peaks and rainfall intensity. This is due to the longer time accumulation results in minimising detection of rainfall fluctuations, while the shorter time accumulation captures higher rainfall variability. In addition, Petty and Krajewski (1996) noted that rainfall rate and short term rain accumulation display high degrees of zero-rain intermittence as seen for the 3-hourly average data. As the time scale increases, the zero-rain intermittence becomes less of a problem and rainfall fields are more continuous.

Meanwhile, rainfall fluctuations of preceding and following the flood events show widely differs from event to event due to magnitude underestimation or overestimation by the GSMaP_MVK satellite estimates with respect to the rain gauge data. The GSMaP_MVK underestimated the rainfall intensity over Medan City, Pekanbaru City, Indragiri Hulu Regency and Manado City, but overestimated over Samarinda City. The GSMaP_MVK are generally overestimated to light rainfall and less sensitive to heavy rainfall. According to 
Barrett (1997), it is intrinsically difficult to establish the rain/no rain boundary with precision because the gradients of rainfall intensity may instead be very shallow, which lead to underestimation or overestimation.

\subsection{Rainfall Pattern Before Floods Occur}

The flood event in Medan City on 5 December 2003 (see Figure 3) indicates irregular rainfall pattern (i.e. not so heavy rainfall, but high rainfall intensity occur several days before flooding) in which the GSMaP_MVK and the rain gauge detected no heavy rainfall about 4 to 5 days before the day of flooding reported. This flood occurrence may be caused by other than rainfall simultaneously.

The flood events in Pekanbaru City and Indragiri Hulu Regency on 21 February 2003 (Figure 5) and in Samarinda City on 7 May 2004 (Figure 7) show short-term pattern (i.e. high intensity accumulative rainfall for several hours until one day before flooding), instead of irregular pattern identified by Aryastana et al. (2012). This confirms that the rainfall is the main cause of the floods as observed by the GSMaP_MVK and the rain gauge data. Meanwhile, the flood event in Manado City on 26 December 2003 (Figure 9) are classified as long-term rainfall pattern with accumulative rainfall several days or more than one day before the flood starts to occur. This shows that the rainfall is considered the possible cause of the flood.

Table 3 shows summary of the rainfall pattern classification before flooding for the research locations. Overall, short-term period rainfall pattern is the most frequent occurred preceding flood events in Medan City, Pekanbaru City \& Indragiri Hulu Regency, Samarinda City and Manado City accounted for about 63.6\%, 60\%, 66.7\% and 66.7\%, respectively. These areas are also known as urban regions with some rivers flows nearby, which likely indicate the regions are more susceptible to flash floods and river overflows.

Table 3. Classification of the rainfall patterns preceding flood events analysed for the research locations

\begin{tabular}{lcccc}
\hline \multirow{2}{*}{ Location } & $\begin{array}{c}\text { Number of Flood } \\
\text { Events }\end{array}$ & Long-Term & Short-Term & Irregular \\
\cline { 3 - 5 } & 11 & 1 & 7 & 3 \\
Medan & 10 & 2 & 6 & 2 \\
$\begin{array}{l}\text { Indragiri Hulu and } \\
\text { Pekanbaru }\end{array}$ & 9 & 2 & 6 & 1 \\
Samarinda & 6 & 1 & 4 & 1 \\
Manado & & & & \\
\hline
\end{tabular}

\subsection{Accuracy Verification of The GSMaP_MVK}

Verification of 3-hourly and daily rainfall intensity of the flood events at study areas using continuous statistic score, i.e. mean error (ME) shows that the GSMAP_MVK data on average underestimates for Medan City, Pekanbaru City \& Indragiri Hulu Regency, and Manado City and overestimates for Samarinda City (Table 4).

Overall, the daily data reveal lower ME, MAE and RMSE than 3-hourly data. The trends of change of the RMSE are similar as the MAE. The daily data provide improvement of the correlation coefficient compared with the 3-hourly data. The MAE and RMSE decrease as the time step increases. This is because of the shorter the time steps the more errors are included (e.g. due to higher variability), while the longer time steps removes the representativeness of errors.

Verification on rainfall events of the flood events at study areas using categorical statistics scores as seen on Table 5 shows that on average the GSMaP_MVK provides moderate to high probability of rain detection (POD) in the range from $0 . \overline{5} 7$ to 0.75 and from 0.93 to 0.99 for 3-hourly and daily data, respectively. The highest POD is found for Pekanbaru City \& Indragiri Hulu Regency, while the lowest is shown for Manado City for 
both the two data. The false alarm ratio (FAR) ranges from 0.36 to 0.64 and from 0.10 to 0.42 for 3-hourly and daily data, respectively. The lowest FAR is shown for Manado City, while the highest is found for Medan city for both the two data. Meanwhile, the threat score (TS) spans from 0.31 to 0.43 and from 0.58 to 0.83 for 3-hourly and daily data, respectively. The highest TS is observed for Manado City, while the lowest is found for Medan City for both the two data.

Table 4. Summary of the continuous statistical verification for the research locations

\begin{tabular}{lcccccccc}
\hline \multirow{1}{*}{ Location } & \multicolumn{4}{c}{ 3-hourly } & \multicolumn{5}{c}{ Daily } \\
\cline { 2 - 9 } & $\begin{array}{c}\mathrm{ME} \\
(\mathrm{mm} / \mathrm{h})\end{array}$ & $\begin{array}{c}\mathrm{MAE} \\
(\mathrm{mm} / \mathrm{h})\end{array}$ & $\begin{array}{c}\mathrm{RMSE} \\
(\mathrm{mm} / \mathrm{h})\end{array}$ & $\mathrm{r}$ & $\begin{array}{c}\mathrm{ME} \\
(\mathrm{mm} / \mathrm{h})\end{array}$ & $\begin{array}{c}\mathrm{MAE} \\
(\mathrm{mm} / \mathrm{h})\end{array}$ & $\begin{array}{c}\mathrm{RMSE} \\
(\mathrm{mm} / \mathrm{h})\end{array}$ & $\mathrm{r}$ \\
\hline Medan & -0.04 & 0.65 & 1.76 & 0.31 & -0.03 & 0.36 & 0.58 & 0.71 \\
Pekanbaru \& & -0.19 & 0.69 & 1.93 & 0.46 & -0.21 & 0.47 & 0.78 & 0.65 \\
Indragiri Hulu & & 0.83 & 2.26 & 0.22 & 0.09 & 0.47 & 0.73 & 0.66 \\
Samarinda & 0.10 & 0.63 & -0.52 & 0.61 & 0.89 & 0.83 \\
Manado & -0.53 & 0.84 & 2.07 & 0.54 & -0.52 & & &
\end{tabular}

Table 5. Summary of the categorical verification statistics scores for the research location

\begin{tabular}{lcccccc}
\hline \multicolumn{1}{c}{ Location } & \multicolumn{3}{c}{ 3-hourly } & & \multicolumn{3}{c}{ Daily } \\
& POD & FAR & TS & POD & FAR & TS \\
\hline Medan & 0.73 & 0.64 & 0.31 & 0.97 & 0.42 & 0.58 \\
Indragiri Hulu & 0.75 & 0.60 & 0.35 & 0.99 & 0.33 & 0.67 \\
\&Pekanbaru & 0.68 & 0.57 & 0.35 & 0.97 & 0.27 & 0.71 \\
Samarinda & 0.57 & 0.36 & 0.43 & 0.93 & 0.10 & 0.83 \\
Manado & & & & & & \\
\hline
\end{tabular}

Overall, as the time steps increases, the POD increases accordingly. The trends of change of the FAR are on the contrary with the POD score. Similar to the POD, the TS increases as the time steps increases. These may be because of the intense rain fell that are in gauge proximity are missed by the satellites snapshot and picked by gauges for shorter period (Crosson et al., 1996). It is expected that for good accuracy of the satellite estimates with respect to the rain gauge measurements, the POD and the TS are as high as possible approaching value of 1 , which represents higher probability of rainfall events is correctly observed or estimated. On the contrary, the lower the FAR score the higher the satellite accuracy. It means less possibility to falsely detected rainfall events in which did not measure by the rain gauge observation.

According to the statistics verification, performance of the GSMaP_MVK differs among the regencies and also from event to event. Local effects, such as terrain profile, near to coastal area with sea and land breeze circulations (e.g. Manado City, Medan City and Samarinda City) may contribute to the results deviation (Islam et al., 2005). Furthermore, retrieval of precipitation using PMW observations has always represented a problem over coastal areas; often techniques omit retrievals over the coastline, or use a less optimum technique (Kidd and Levizzani, 2011; Kidd and Huffman, 2011; Kelkar, 2007).

\section{Conclusions}

Based on the objectives of this study and the results obtained, some concluding remarks can be drawn as follows:

a. The GSMaP_MVK product provides promising potentiality for the application of monitoring rainfall conditions preceding flood events in Indonesia, especially in Medan City, Pekanbaru City, Indragiri Hulu Regency, Samarinda City and Manado City. The GSMaP_MVK performs underestimation for the most areas, except Samarinda City, which is overestimated. 
b. Comparisons of the GSMaP_MVK with the rain gauge data show discrepancies in capturing rainfall events and intensity of preceding and following the flood events in Medan City, Pekanbaru City \& Indragiri Hulu Regency, Samarinda City and Manado City. However, the GSMaP_MVK product quite matches in detecting rainfall occurrences. The three-hourly observations show less matching than the daily data. This is due to the shorter time accumulation captures higher rainfall variability. Thus, the reliability of the GSMaP_MVK with respect to the rain gauge observations reduces for the 3-hourly data as compared with the daily data.

c. Both the GSMaP_MVK and the rain gauge observations agree that no heavy rainfall detected before the flood began, which indicated irregular rainfall pattern for the flood events in Medan City on 5 December 2003 and in Samarinda City on 25 January 2004. These flood occurrences may be caused by other than rainfall simultaneously.

d. Short-term period rainfall pattern is the most frequent occurred preceding flood events in Medan City, Pekanbaru City \& Indragiri Hulu Regency, Samarinda City and Manado City accounted for about $63.6 \%, 60 \%, 66.7 \%$ and $66.7 \%$, respectively, which indicate that these areas are more susceptible to flash floods and river overflows.

\section{References}

Aonashi, K., \& Liu, G. (2000). Passive microwave precipitation retrievals using TMI during the Baiu period of 1998. Part I: Algorithm description and validation. Journal of Applied Meteorology, 39(12), 2024-2037.

Aryastana, P., Tanaka, T., \& Mahendra, M. S. (2012). Characteristic of rainfall pattern before flood occur in Indonesia based on rainfall data from GSMaP. Ecotrophic: Journal of Environmental Science, 7(2), 100-110.

BNPB. 2013. Data Informasi Bencana Indonesia. National Agency for Disaster Management (BNPB) of Indonesia [online]. Available at: http://www.bnpb.go.id/.

Barrett, E. C. (1997). Satellite rainfall monitoring: recent progress and remaining problems. IAHS Publications-Series of Proceedings and Reports-Intern Assoc Hydrological Sciences, 242, 141-148.

Ciach, G. J., \& Krajewski, W. F. (1999). On the estimation of radar rainfall error variance. Advances in Water Resources, 22(6), 585-595.

Crosson, W. L., Duchon, C. E., Raghavan, R., \& Goodman, S. J. (1996). Assessment of rainfall estimates using a standard ZR relationship and the probability matching method applied to composite radar data in central Florida. Journal of Applied Meteorology, 35(8), 1203-1219.

Ebert, E. E. (2007). Methods for verifying satellite precipitation estimates. In Levizzani, V., Bauer, P., $\&$ Turk, F.J. (Eds). Measuring Precipitation from Space: EURAINSAT and the Future. Netherlands: Springer. pp. 345-356.

Harris, A., Rahman, S., Hossain, F., Yarborough, L., Bagtzoglou, A. C., \& Easson, G. (2007). Satellite-based flood modeling using TRMM-based rainfall products. Sensors, 7(12), 3416-3427.

Islam, M. N., Terao, T., Uyeda, H., Hayashi, T., \& Kikuchi, K. (2005). Spatial and temporal variations of precipitation in and around Bangladesh. Journal of the Meteorological Society of Japan. Ser. II, 83(1), 21-39.

Kelkar, R.R. (2007). Satellite meteorology. Andhra Pradesh, India: BS Publisher.

Kidd, C., Kniveton, D. R., Todd, M. C., \& Bellerby, T. J. (2003). Satellite rainfall estimation using combined passive microwave and infrared algorithms. Journal of Hydrometeorology, 4(6), 10881104.

Kidd, C., \& Huffman, G. (2011). Global precipitation measurement. Meteorological Applications, 18(3), 334-353.

Kidd, C., \& Levizzani, V. (2011). Status of satellite precipitation retrievals. Hydrology and Earth System Sciences, 15(4), 1109-1116.

Kubota, T., Shige, S., Hashizume, H., Aonashi, K., Takahashi, N., Seto, S., Hirose, M., Takayabu, Y. N., Ushio, T., Kachi, M., \& Okamoto, K. (2007). Global precipitation map using satellite-borne microwave radiometers by the GSMaP project: Production and validation. IEEE Transactions on Geoscience and Remote Sensing, 45(7), 2259-2275.

Mustafa, M. (2007). Validation of Satellite-based Rainfall Estimation over the Limpopo Basin. (Master Thesis). Zimbabwe: University of Zimbabwe, Zimbabwe, University of Zimbabwe.

Okamoto, K., Takahashi, N., Iwanami, K., Shige, S., \& Kubota, T. (2008). High precision and high resolution global precipitation map from satellite data. In Microwave Radiometry and Remote Sensing of the Environment 2008 (MICRORAD 2008). Niigata-Japan. 
Petty, G. W., \& Krajewski, W. F. (1996). Satellite estimation of precipitation over land. Hydrological sciences journal, 41(4), 433-451.

Seto, S., Tsunekawa, T., \& Oki, T. (2012). A new rain detection method to complement highresolution global precipitation products. Hydrological Research Letters, 6, 82-86.

Sinclair, S., \& Pegram, G. (2005). Combining radar and rain gauge rainfall estimates using conditional merging. Atmospheric Science Letters, 6(1), 19-22.

Sorooshian, S., AghaKouchak, A., Arkin, P., Eylander, J., Foufoula-Georgiou, E., Harmon, R., Hendrickx, J., Imam, B., Kuligowski, R., Skahill, B., \& Skofronick-Jackson, G. (2011). Advanced concepts on remote sensing of precipitation at multiple scales. Bulletin of the American Meteorological Society, 92(10), 1353-1357.

Strangeways, I. (2007). Precipitation: theory, measurement and distribution. Cambridge, England: Cambridge University Press.

Tian, Y., Peters-Lidard, C. D., Adler, R. F., Kubota, T., \& Ushio, T. (2010). Evaluation of GSMaP precipitation estimates over the contiguous United States. Journal of Hydrometeorology, 11(2), 566-574.

Ushio, T., Sasashige, K., Kubota, T., Shige, S., Okamoto, K. I., Aonashi, K., Inoue, T., Takahashi,. N., Iguchi, T., Kachi, M., Oki, R., Morimoto, T., \& Kawasaki, Z.-I. (2009). A Kalman filter approach to the Global Satellite Mapping of Precipitation (GSMaP) from combined passive microwave and infrared radiometric data. Journal of the Meteorological Society of Japan. Ser. II, 87, 137-151.

WMO. (2011). Guide to climatological practices, 2011 edition, WMO No. 100. Geneva, Swiss: Secretariat of the World Meteorological Organization (WMO).

(C) 2017 by the authors; licensee Udayana University, Indonesia. This article is an open access article distributed under the terms and conditions of the Creative Commons Attribution (CC-BY) license (http://creativecommons.org/licenses/by/4.0/). 